\title{
Diversity, structure and composition of vegetation in post-coal mining reclamation area in Sumatra, Indonesia
}

\author{
LULU YUNINGSIH ${ }^{1,2, \vartheta}$, HERMANSYAH ${ }^{1,3, v \vee}$, EDDY IBRAHIM ${ }^{1,4}$, MARSI $^{1,5}$ \\ ${ }^{1}$ Program of Environmental Science, Graduate School, Universitas Sriwijaya. Jl. Padang Selasa, Bukit Besar, Palembang 30139, South Sumatra, \\ Indonesia. \\ Tel.: +62-813-77530575, Fax.: +62-711-511731,`email: lulu.hutumpalembang@ gmail.com \\ ${ }^{2}$ Program of Forestry, Muhammadiyah University of Palembang, Jl. Jenderal A. Yani, Plaju, Palembang 30263, South Sumatra, Indonesia \\ ${ }^{3}$ Department of Chemistry, Faculty of Mathematics and Natural Sciences, Universitas Sriwijaya. Jl. Raya Palembang-Prabumulih Km.32, Inderalaya, \\ Ogan Ilir 30662, South Sumatra, Indonesia. Tel.: +62-821-82532570; Fax.: +62-711-580268, v email: hermansyah@unsri.ac.id \\ ${ }^{4}$ Department of Mine, Faculty of Engineering, Universitas Sriwijaya. Jl. Raya Palembang-Prabumulih Km. 32, Inderalaya, Ogan Ilir 30662, South \\ Sumatra, Indonesia \\ ${ }^{5}$ Department of Soil, Faculty of Agriculture, Universitas Sriwijaya. J1. Raya Palembang-Prabumulih Km. 32, Inderalaya, Ogan Ilir 30662, South Sumatra, \\ Indonesia
}

Manuscript received: 26 June 2021. Revision accepted: 23 July 2021.

\begin{abstract}
Yuningsih L, Hearmansyah, Ibrahim E, Marsi. 2021. Diversity, structure and composition of vegetation in post-coal mining reclamation area in Sumatra, Indonesia. Biodiversitas 22: 3392-3400. The majority of coal mines are operated through an open-pit system which has a significant impact on the environment. Therefore, reclamation and revegetation activities are required to recover ecological sustainability. This study aimed to analyze the diversity, structure, and composition of vegetation resulting from the postmining revegetation process in a mining concession in Sumatra, Indonesia at various intervals of post-reclamation periods, namely 11 years, 10 years, 8 years, and 5 years. Data collection was conducted by sampling with a 2.5 percent intensity. The study discovered 23 species of naturally grow understory plants and 25 species of woody plants. The stand structure at the eleventh, tenth, and eighth years of revegetation resembled an inverted J curve. The Species Richness Index $(\mathrm{R})$ was determined to be low, the Shannon diversity index $(\mathrm{H}$ ') was is low to moderate, whereas the evenness index was moderate to high. We concluded that the structure of vegetation in the post-mining reclamation region resembled that of a natural forest ecosystem, yet the biodiversity indicators remain low and below those of natural forest. We expected the result of this study can enrich the limited knowledge of the ecology of post-mining reclamation in the tropics.
\end{abstract}

Keywords: Post-coal mining, revegetation, reclamation, vegetation

\section{INTRODUCTION}

Coal mining operation is generally carried out using open-pit system. The open-pit mining activities are started with land clearing, overburden removal, soil loading, coal extraction, and hauling (Triantoro 2017). This system is indicated to cause damage 2-11 times higher than underground mining (Zhongke et al. 1999). Open-pit mining system removes vegetation cover, disturbs the ecological balance of soil surface, and reduces environmental productivity and quality (Kumar 2013). In addition, the system may also affect the physical, chemical and biological properties of terrestrial structures (e.g., soil, flora, fauna, landscapes, historical and archaeological objects), aquatic features (e.g., hydrology, hydrogeology, water quality, aquatic biota), and the atmosphere (e.g., climate, air quality) in the surrounding area (Toren 2002; Ghose 2005; Haibin and Zhenling 2010; Favas et al. 2018; Lestari et al. 2019).

Post-mining land reclamation is an effort to manage, restore and improve the quality of the environment and ecosystems that have been disturbed by mining operations in order to stabilize the soil surface in the long term and make it suitable to be used for production activities. The process of post-mining reclamation begins with soil preparation for replanting as the first step to build a new ecosystem (Setiadi and Adinda 2013). Reclamation also includes some measures to stabilize post-mining areas aimed to prevent erosion or to retain runoff water, and to prepare the land to be more stable and productive (Yani 2005).

One of post-mining reclamation activities is revegetation that is expected to form a new ecosystem after mining to be more sustainable. Revegetation is the easiest way to restore land productivity and vegetation cover in disrupted areas, and to improve soil quality and microclimate (Singh et al. 2002; Sheoran et al. 2010). According to Witno et al. (2018), the positive benefits of post-mining reclamation and revegetation, among others, are recovering biodiversity and soil fertility, attracting wild animals to inhabit, and improving environmental shape, land cover and canopy stratification, as well as the ability to absorb and store carbon to create a microclimate.

The development of vegetation grows dynamically through several succession (Martono 2012; Hapsari et al., 2020). Accordingly, the succession processes following revegetation in post-mining reclamation areas will also go through several stages depending on the age, level of disturbance, management intervention, and environmental conditions. Nonetheless, it is not clear the trajectory of 
vegetation succession in revegetated open-pit coal mining, moreover in a complex yet less explored ecosystem such as in tropical regions.

This study aimed to analyze the structure and composition of vegetation resulting from the post-mining revegetation process in a mining concession in Sumatra, Indonesia at various intervals of post-reclamation periods, namely 11 years, 10 years, 8 years, and 5 years. We expected the result of this study can enrich the limited knowledge of the ecology of post-mining reclamation in the tropics as well as contribute to policy and management interventions.

\section{MATERIALS AND METHODS}

\section{Study period and area}

The research was conducted in November 2020 at the post-coal mining revegetation area of a mining concession company located in Tanjung Enim, Muara Enim District, South Sumatra Province, Indonesia (Figure 1). The Mining Business Permit (Ijin Usaha Pertambangan/IUP) of the company covers an area of 40,347 ha in which $18,233.29$ ha (equal to $45.19 \%$ ) of the concession areas have forest status. Up to this day, the company operation has cleared
$6,610.74$ ha of the total concession area. Whereas the reclamation activities have been carried out in $2,142.52$ ha or $32 \%$ of the post-mined sites

The original land cover before mining operation was secondary forest, shrubs and mixed plantation with vegetation of various habitus and species. This vegetation definitely added a positive impact on the ecological balance in terms of microclimate, improvement of the physical, chemical and biological properties of the soil, water management systems and flora and fauna conservation (Arrijani et al. 2006).

\section{Sampling procedure and sample size}

Sampling intensity of $2.5 \%$ was used to determine the number of samples in this study. This intensity is higher than the requirement for stocktaking timber forest resources in a mature but unfit plantation which is $0.5 \%$ (Ministry of Forestry Regulation P.67/Menhut-II/2006). The plot size was $20 \mathrm{~m}$ x $20 \mathrm{~m}$ made lengthwise to form a path (Rusolono et al. 2015). From each plot, data on woody plant species from various strata (seedlings, saplings, poles, trees), and understorey as well as data on the number of individuals were collected. However, only trees from sapling strata with diameter $\geq 5 \mathrm{~cm}$ were measured.

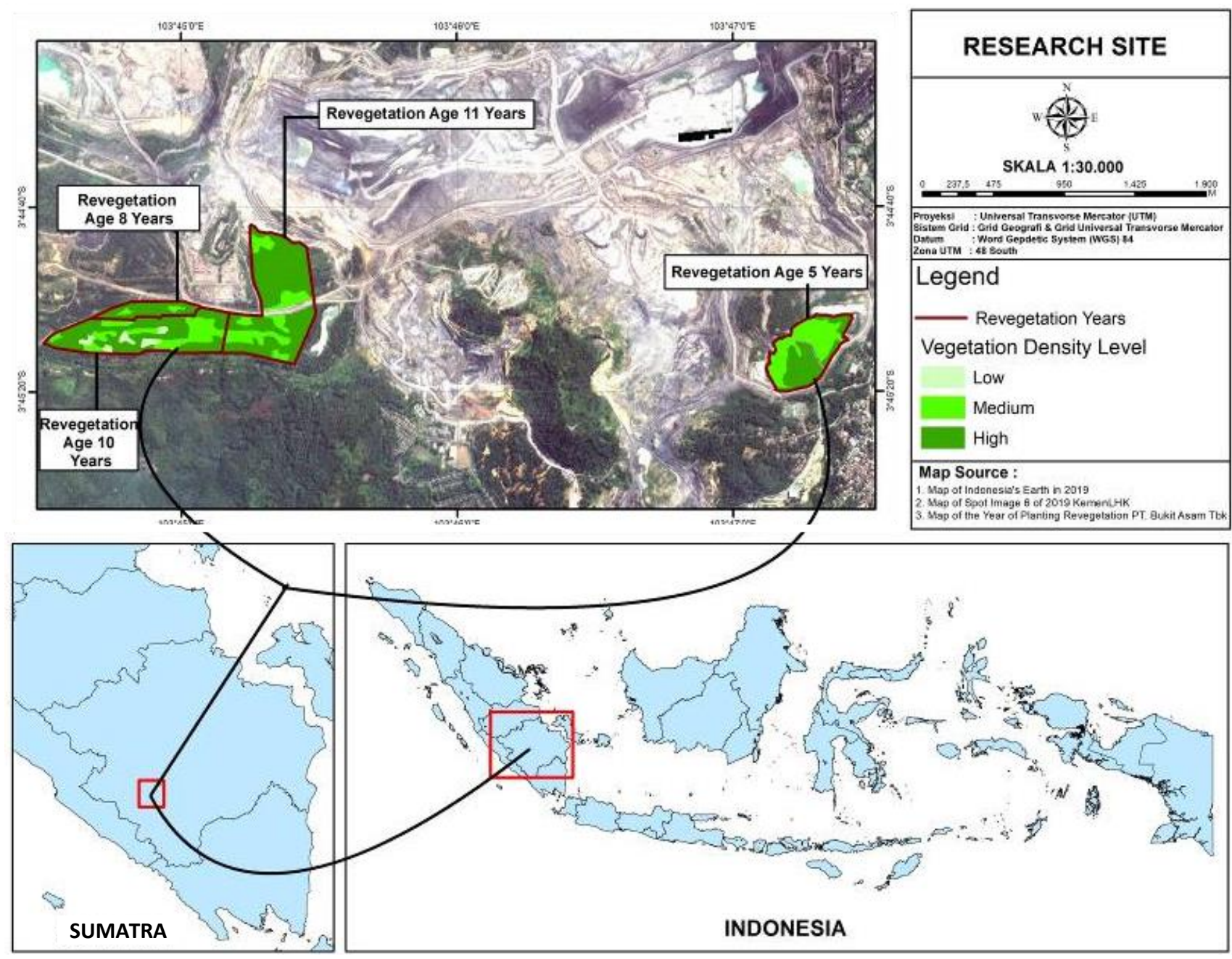

Figure 1. Map of research site at the post-coal mining revegetation area of a mining concession company located in Tanjung Enim, Muara Enim District, South Sumatra Province, Indonesia 
The vegetations are classified based on the following strata: (i) Understorey that consists of shrubs, bushes, lianas, herbs and ferns (Istomo et al. 2016). (ii) Seedlings: small trees with height $<1.5 \mathrm{~m}$ and diameter $<5 \mathrm{~cm}$. (iii) Saplings: woody plant with height $\geq 1.5 \mathrm{~m}$ and diameter $5 \mathrm{~cm} \leq \varnothing<10 \mathrm{~cm}$. (iv) Poles: woody plants with diameter 10 $\mathrm{cm} \leq \varnothing<20 \mathrm{~cm}$. (v) Trees: woody plants with diameter $\emptyset \geq$ 20cm (Rusolono et al. 2015; Septiawan et al. 2016).

\section{Data collection}

Data collected in this study was taken from post-coal mining revegetation areas which have been planted for 11 years, 10 years, 8 years and 5 years. The sample selection was determined based on land cover vegetation density by overlaying Spot 6 high-resolution satellite imagery (CSRT) and the revegetation map of the company using ArcGis software. The data collection activity started with overlaying images based on the shape, tone, texture, pattern, size, shadow, site, association and convergence of visible evidence. Subsequently, the images were classified using the delineation technique to obtain three levels of vegetation density (i.e., high, medium and low density) (BSN 2014).
Vegetation density in locations with 11 years, 8 years and 5 years of revegetation years are classified into two categories namely the dense and medium levels. As for the location with 10-year revegetation age, there are three levels of vegetation density: dense, medium and sparse. Total area of each vegetation density level is presented in Table 1.

The number and distribution of plots is defined to allocate measurement plots so as to increase the accuracy of sampling data. The number of plots that have been determined based on a sampling intensity of at least $2.5 \%$ is then distributed in locations based on the results of overlaying the revegetation ages and vegetation density levels as shown in Figure 2.

Table 1. Information of research sites with varying vegetation densities and revegetation ages

\begin{tabular}{cccccc}
\hline $\begin{array}{c}\text { Planting } \\
\text { Year }\end{array}$ & $\begin{array}{c}\text { Re- } \\
\text { vegetation } \\
\text { age }\end{array}$ & $\begin{array}{c}\text { Total } \\
\text { area } \\
\text { (ha) }\end{array}$ & $\begin{array}{c}\text { High- } \\
\text { density } \\
\text { area }\left(\mathbf{m}^{\mathbf{2}}\right)\end{array}$ & $\begin{array}{c}\text { Medium- } \\
\text { density } \\
\text { area }\left(\mathbf{m}^{\mathbf{2}}\right)\end{array}$ & $\begin{array}{c}\text { Low- } \\
\text { density } \\
\text { area }\left(\mathbf{m}^{\mathbf{2}}\right)\end{array}$ \\
\hline 2009 & 11 & 34.33 & 305,537 & 37,763 & \\
2010 & 10 & 26.40 & 187,440 & 50,160 & 26,400 \\
2012 & 8 & 5.03 & 33,701 & 16,599 & \\
2015 & 5 & 3.90 & 37,050 & 1,950 & \\
\hline
\end{tabular}
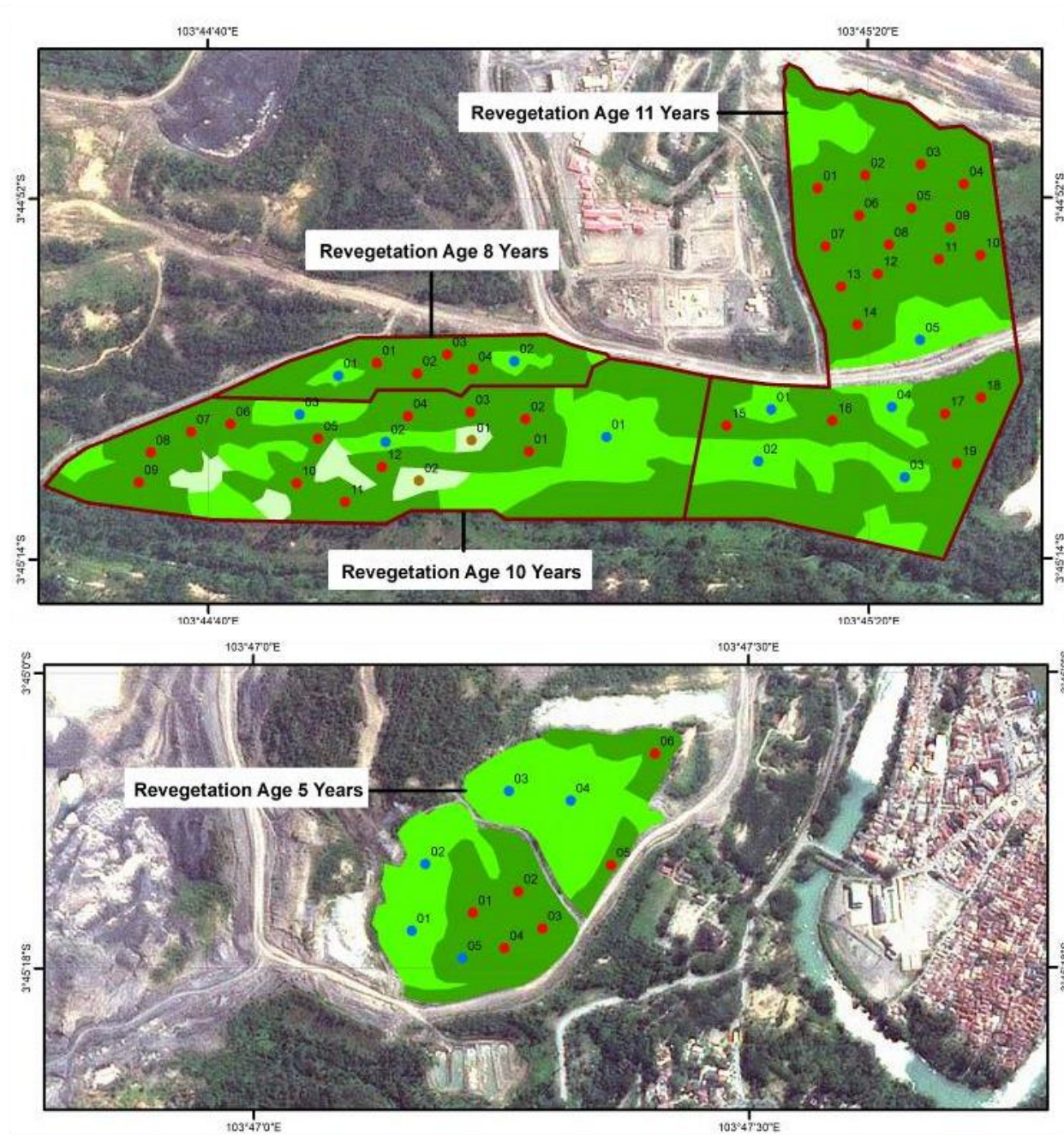

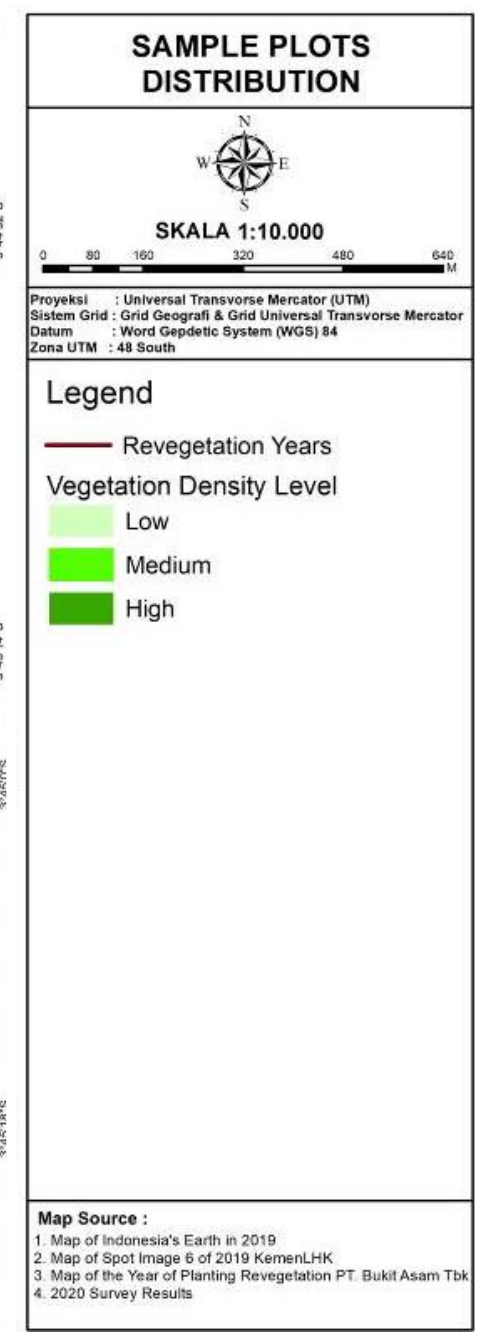

Figure 2. Distribution of sampling plots with varying vegetation density levels and revegetation ages (i.e., 11, 10, 8 and 5 years) 
According to secondary data provided by the company, prior to the replanting, there was soil preparation. The soil heap overlaid at the revegetation location was then covered with humus, and the $\mathrm{pH}$ was checked. If the $\mathrm{pH}$ was still acidic $(\leq 5)$, liming was then applied with 3 tons of bokashi fertilizer per hectare. Soil $\mathrm{pH}$ is a very influential factor in vegetation growth in the reclamation site (Lestari et al. 2019). After the liming, the $\mathrm{pH}$ was re-checked and only after the $\mathrm{pH}$ was around 5.5-7.5, then the planting was conducted.

In addition, civil construction to control water flow and to prevent water inundation was made. The plant species is a combination of selected pioneer wood species and local superior wood species. In the first planting phase, pioneer plants (i.e., Melaleuca cajuputi, Cassia siamea, Acacia mangium, Acacia auriculiformis, Pterocarpus indicus, Enterolobium cyclocarpum, Adenanthera pavonina, Samanea saman, and Delonix regia) were planted with a spacing of $4 \times 4 \mathrm{~m}$ and $4 \times 6 \mathrm{~m}$. Research by Pamoengkas et al. (2020) found that $4 \times 6 \mathrm{~m}$ spacing resulted in better height and diameter for woody plants, S. leprosula. As for $M$. cajuputi (eucalyptus), a spacing of $3 \times 3 \mathrm{~m}$ is sufficient because it has a light canopy. In the next period, local superior vegetation (i.e., Intsia palembanica, Nauclea orientalis, Hibiscus tiliaceus, Aquilaria malaccensis, and Muntingia calabura L.) were planted after the pioneer plants reached a minimum age of two years old. The size of planting hole was $30 \times 30 \mathrm{~cm}$ with $25 \mathrm{~cm}-30 \mathrm{~cm}$ depth, and \pm 3 $\mathrm{kg}$ of bokashi fertilizer was added to the hole. If the planting was carried out in the dry season, $\pm 1.5 \mathrm{~kg}$ of hydrogel was then added to the hole. During the first three years of cultivation, intensive maintenance was conducted every six months including weeding, soil tiling, pests, and diseases controlling, fertilizing, and replanting the dead plants.

\section{Data analysis}

Vegetation communities and diversity were analyzed using species density $(\mathrm{K})$, relative density $(\mathrm{KR})$, frequency $(F)$, relative frequency (FR), dominance (D), relative dominance (DR), importance value index (IVI), calculation of specific richness index $(\mathrm{R})$, diversity index $\left(\mathrm{H}^{\prime}\right)$ and evenness index $(\mathrm{E})$. The formulas used for each of these variables are as follows:

Importance value index

For pole and tree $=\mathrm{KR}+\mathrm{FR}+\mathrm{DR}$

For seedling and sapling $=\mathrm{KR}+\mathrm{FR}$

Specific richness index $(\mathrm{R})$, diversity index $\left(\mathrm{H}^{\prime}\right)$ and evenness index are calculated using this formula:
$\mathrm{R}=(\mathrm{S}-1) \ln (\mathrm{N})$
$\mathrm{H}^{\prime}=-\Sigma[(\mathrm{Pi}) \ln (\mathrm{Pi})]$
$\mathrm{E}=\mathrm{H}^{\prime} / \ln \mathrm{S}$
Where:
$\mathrm{R} \quad$ : specific richness index
$\mathrm{H}^{\prime}$ : diversity index
E : evenness index
$\mathrm{S} \quad$ : number of species
$\mathrm{N}$ : number of specific species
$\mathrm{Pi} \quad: \mathrm{ni} / \mathrm{N}$
ni : INP of each species
$\mathrm{N} \quad$ : total INP of all species

\section{RESULTS AND DISCUSSION}

\section{Plant species diversity in varying revegetation ages}

The results in post-coal mining revegetation areas that have been planted for 11 years, 10 years, 8 years and 5 years show that the seedlings have entirely grown into saplings, poles, and trees, in sequence. This finding indicates that the vegetation is in good growth and succession processes which are characterized by the species composition, density and dominance.

The woody plants from each strata/stage at the age of 11 years consisted of 6-9 species, 3-7 species at the age of 10 years, 3-9 species at the age of 8 years, and 2-7 species at the age of 5 years (Table 2). This number of species indicates a better condition in post-mining revegetation areas compared to degraded natural forests. Research by Kusumo et al. (2016) found that in the natural forest of a national park, 18 species were identified at seedling level, 16 species at sapling level, 15 species at pole level, and 34 species at tree level, while in degraded forest a total of 2 species were found at seedling level, 4 species at sapling level, 5 species at pole level, and 5 species at tree level.

Understorey vegetation is naturally growth plants developed during the succession process of a forest. The total number of understorey species at revegetation ages consisted of 23 species, with 14 species at the age of 11 years, 15 species at the age of 10 years, 6 species at the age of 8 years, and 10 species at the age of 5 years (Table 2). The number of understorey species is in line with the research finding of Komara et al. (2016) who discovered 28 species after 16 years of reclamation and revegetation.

The structure of seedlings, saplings, poles, and trees was developed through the combination of species that were planted and other species that grew naturally. The woody plant species consisted of cultivated species, natural species resulting from natural regeneration of the planted plants (natural plant regeneration), and naturally growing species resulting from the succession process (natural plant succession). Of the 25 woody plant species recorded in Table 2, there were four species that grew naturally from the regeneration of the initial plant being planted, including Acacia auriculiformis, Acacia mangium, Melaleuca leucadendra, Hibiscus tilliaceus, and five species of woody plants that grew naturally as a result of succession namely Mallotus paniculatus, Grewia tomentosa, Bridelia tomentosa, Vitex pinnata, Litsea umbellata. The distribution pattern of naturally growing plants in each stratum and revegetation age is presented in Table 3.

The five plant species that grew naturally as the byproduct of succession process in post-mining zone is made up to $20 \%$ of the total woody vegetation. This number is consistent with the results of previous research (Komara et al. 2016) that found 16 tree species grew naturally or $21 \%$ of the 78 tree species that existed in postmining areas after 16 years of revegetation.

The vegetation at post-mining site in this study has gone through a regeneration process as indicated by the natural growth of the planted species by $16 \%$. The condition also reveals that there is a similar association that affects the regeneration and distribution of species (Murdjoko et al. 2020). 
Table 2. List of species in varying strata/stages and revegetation ages (years after the planting)

\begin{tabular}{|c|c|c|c|c|c|}
\hline Species & Understorey & Seedling & Sapling & Poles & Tree \\
\hline Acacia auriculiformis & & 11 & & 8 & $11-8$ \\
\hline Acacia mangium & & $10-8-5$ & $11-10-8-5$ & $11-10-8-5$ & $11-10-8$ \\
\hline Adenanthera pavonina & & & & & 10 \\
\hline Aquilaria malaccensis & & & & 5 & \\
\hline Borreria sp $p^{*}$ & 5 & & & & \\
\hline Bridelia tomentosa & & $11-10-8$ & 11 & 11 & \\
\hline Calopogonium mucunoides $*$ & 5 & & & & \\
\hline Cassia siamea & & & 10 & $11-10-8-5$ & $11-10$ \\
\hline Centrosema pubescens* & 5 & & & & \\
\hline Chromolaena odorata* & $11-10-5$ & & & & \\
\hline Coffea liberica* & $11-10$ & & & & \\
\hline Delonix regia & & & 5 & 5 & 5 \\
\hline Dillenia eximia & & 8 & & & \\
\hline Eleocharis dulcis* & 8 & & & & \\
\hline Eleusia indica* & $8-5$ & & & & \\
\hline Enterolobium cyclocarpium & & & $8-5$ & $11-10-8-5$ & $11-10-8-5$ \\
\hline Gliricidia sepium & & & & 11 & \\
\hline Grewia tomentosa & & 8 & 8 & & \\
\hline Heteropogon contortus* & $10-5$ & & & & \\
\hline Hibiscus tiliaceus & & $11-8$ & $11-10$ & $11-10$ & $11-10$ \\
\hline Imperata cylindrica* & $11-10-5$ & & & & \\
\hline Intsia palembanica & & $11-10-8$ & 8 & 8 & \\
\hline Litsea umbellata & & 11 & & & \\
\hline Mallotus paniculatus & & & $11-10$ & & \\
\hline Melaleuca cajuputi & & 11 & $11-8$ & $11-10-8$ & $11-10$ \\
\hline Melastoma malabathricum* & $11-10-8$ & & & & \\
\hline Micania micrantha* & 10 & & & & \\
\hline Micromelum minutum* & $11-10$ & & & & \\
\hline Mimosa pigra* & $11-10$ & & & & \\
\hline Mimosa pudica* & $11-5$ & & & & \\
\hline Muntingia calabura & & & 5 & 5 & \\
\hline Nauclea orientalis & & 8 & 11 & 11 & \\
\hline Paspalum commersonii $*$ & 5 & & & & \\
\hline Paspalum conjugatum* & $11-10-8-5$ & & & & \\
\hline Physalis angulata* & 10 & & & & \\
\hline Pterocarpus indicus & & & 5 & 5 & 11 \\
\hline Samanea saman & & & & & 11 \\
\hline Sauropus androgymus* & $11-10$ & & & & \\
\hline Shorea javanica & & 5 & & & \\
\hline Solanum jamaicense* & 11 & & & & \\
\hline Sphagneticola trilobata* & $11-10-8$ & & & & \\
\hline Stenochlaena palustris* & $11-10-8$ & & & & \\
\hline Swietenia macrophylla & & 12 & $11-10-8$ & & \\
\hline Tamarindus indica & & & & & $11-10$ \\
\hline Tectona grandis & & & 5 & & \\
\hline Tetracera indica* & $11-10$ & & & & \\
\hline Urena lobata* & $11-10$ & & & & \\
\hline Vitex pinnata & & 8 & & & \\
\hline
\end{tabular}

Notes: *: Naturally grow understorey species; $11,10,8,5$ : years of revegetation age

Table 3. List of natural woody plant species in each structure at varying revegetation ages

\begin{tabular}{|c|c|c|c|c|}
\hline Species & Seedling & Sapling & Poles & Tree \\
\hline Acacia auriculiformis & $11(N P R)$ & & $8(C P)$ & $11-8(C P)$ \\
\hline Acacia mangium & $10-8-5(N P R)$ & $11-10-8-5(N P R)$ & $11-10-8-5(C P)$ & $11-10-8(C P)$ \\
\hline Bridelia tomentosa & $11-10-8(N P S)$ & $11(N P S)$ & $11(N P S)$ & \\
\hline Grewia tomentosa & $8(N P S)$ & $8(N P S)$ & & \\
\hline Hibiscus tiliaceus & $11-8(N P R)$ & $11-10$ (NPR) & $11-10(C P)$ & $11-10(C P)$ \\
\hline Litsea umbellata & $11(N P S)$ & & & \\
\hline Mallotus paniculatus & & $11-10(N P S)$ & & \\
\hline Melaleuca cajuputi & $11(N P R)$ & $11-8(N P R)$ & $11-10-8(C P)$ & $11-10(C P)$ \\
\hline Vitex pinnata & 8 (NPS) & & & \\
\hline
\end{tabular}

Note: NPR: Natural Plant Regeneration; NPS: Natural Plant Succession; CP: Cultivated Plant; 11, 10, 8, 5: Revegetation age (years) 
The comparable association value of $16 \%$ from 25 woody plant species displayed a very low value compared to the vegetation association pattern in lowland tropical forests, that is 66 of 149 tree species or equivalent to $44 \%$, (Murdjoko et al. 2020). Nonetheless, the process to achieve a climax forest condition will take decades.

\section{Structure and composition of vegetation community}

Vegetation density is a parameter that shows the number of individuals of all species in one hectare (in trees/ha unit). The horizontal structure of a specific stand can be identified by the density of each stratum at different revegetation ages (Table 4) or displayed as a curve (Figure $3)$. The curve represents the structural pattern clearly. Based on Figure 3, the structure of vegetation stands at $11^{\text {th }}$ years, $10^{\text {th }}$ years, and $8^{\text {th }}$ years shows that the highest density values are in seedling, sapling, pole, and tree strata, respectively.

These findings show that the stand structure on postmining reclamation area that has been revegetated for 11 years, 10 years, and 8 years resembles an inverted $\mathrm{J}$ shape. The inverted $\mathrm{J}$ curve indicates that small-size plants tend to be denser than larger trees. The small plants are denoted as seedlings, because seedlings are potential plants in the future. The availability of an adequate level of regeneration is one of the prerequisites for constant natural regeneration of an ecosystem (Fajri and Garsetiasih 2019). This higher number of small plants signifies that vegetation growth in the post-coal mining reclamation area after 11 years, 10 years and 8 years of revegetation has resembled a natural forest ecosystem in terms of the structure (based on the number of trees). The allotment of horizontal structure of a natural forest stand, in general, tends to look like an inverted J configuration (negative exponential) (Gunawan et al. 2011). According to Kuswandi et al. (2015), the number of trees and stand structure may describe the availability level of stand in every growth stage, so that both the number and structure affect the ability of regeneration or stand growth, including the recovery rate. The capability of certain plant species to grow into poles and trees levels illustrates the higher adaptability of these species in an ecosystem (Gunawan et al. 2011). A wideranging vegetation structure (from seedling to tree) with moderate diversity has a positive impact on better microclimate and improves soil quality and productivity on post-mining terrestrial (Fajri and Garsetiasih 2019).

The $\mathrm{K}$ value for understorey vegetation is relatively high (Table 4), but understorey does not retain the potential to grow into woody plants in the future. However, they spread on the soil surface to form a layer that has an effect on the physical, chemical and biological properties of the soil. The presence of plants at the seedling level and understorey will help the process of loosening the soil, while at the same time defending against erosion (Sembiring 2008). The varying stand conditions will provide variations in stand ecological characteristics which include diversity ( $\mathrm{Ng}$ et al. 2009) and species richness (Sodhi et al. 2010). This condition may also attract various animal species living on the ground and on trees to inhabit (Kuswandana 2010). Research conducted by Paga et al. (2021) found that the secondary forest ecosystem in Timor Island which is dominated by the pole strata is inhabited more by the Timor bird (Philemon inornatus). The natural ecological process in ex-mining areas will go through succession with pioneer species over six years, (Mukhtar and Heriyanto 2012).

Table 4. The structure and composition of vegetation community in varying strata and revegetation ages

\begin{tabular}{|c|c|c|c|c|c|c|c|c|}
\hline \multirow{2}{*}{$\begin{array}{c}\text { Revegetation } \\
\text { age (years) }\end{array}$} & \multirow{2}{*}{ Stratum } & \multirow{2}{*}{$\begin{array}{c}\text { Number } \\
\text { of species }\end{array}$} & \multirow{2}{*}{$\begin{array}{c}\text { K Total } \\
\text { (tree/ha) }\end{array}$} & \multirow{2}{*}{$\begin{array}{c}\text { Frequency of } \\
\text { value }\end{array}$} & \multirow{2}{*}{$\begin{array}{l}\text { Diameter } \\
\text { (cm) }\end{array}$} & \multirow{2}{*}{$\begin{array}{c}\text { D } \\
\left(\mathbf{m}^{2} / \mathrm{ha}\right)\end{array}$} & \multicolumn{2}{|l|}{ Highest IVI } \\
\hline & & & & & & & Species & Value \\
\hline \multirow[t]{5}{*}{11} & Understorey & 14 & 96,562 & $0.04-0.88$ & - & - & Paspalum conjugatum & 87.22 \\
\hline & Seedling & 6 & 3,127 & $0.04-0.13$ & - & - & Hibiscus tiliaceus & 58.32 \\
\hline & Sapling & 7 & 551 & $0.04-0.21$ & $5.1-9.4$ & 2.27 & Acacia mangium & 122.83 \\
\hline & Pole & 8 & 343 & $0.04-0.38$ & $10-19$ & 5.67 & Cassia seamea & 97.92 \\
\hline & Tree & 9 & 114 & $0.04-0.79$ & $20-45$ & 9.10 & Acacia mangium & 159.11 \\
\hline \multirow[t]{5}{*}{10} & Understorey & 15 & 90,589 & $0.06-0.47$ & - & - & Sphagneticola trilobata & 42.07 \\
\hline & Seedling & 3 & 1,764 & $0.06-0.12$ & - & - & Acacia mangium & 90.00 \\
\hline & Sapling & 5 & 354 & $0.06-0.24$ & $5.5-9.7$ & 1.57 & Acacia mangium & 162.32 \\
\hline & Pole & 5 & 311 & $0.06-0.41$ & $10-19$ & 4.59 & Cassia seamea & 105.16 \\
\hline & Tree & 7 & 113 & $0.06-0,94$ & $20-45.5$ & 8.55 & Acacia mangium & 187.47 \\
\hline \multirow[t]{5}{*}{8} & Understorey & 6 & 81,250 & $0.17-0.50$ & - & - & Paspalum conjugatum & 71.28 \\
\hline & Seedling & 9 & 25,000 & $0.17-0.33$ & - & - & Intsia bijuga & 61.51 \\
\hline & Sapling & 6 & 1,000 & $0.17-0.67$ & $5-9.8$ & 4.04 & Acacia mangium & 110.92 \\
\hline & Pole & 6 & 283 & $0.17-0.50$ & $10-9.7$ & 4.56 & Acacia mangium & 98.24 \\
\hline & Tree & 3 & 50 & $0.17-0.17$ & $20.8-40.5$ & 4.07 & Enterolobium cyclocarpum & 166.71 \\
\hline \multirow[t]{5}{*}{5} & Understorey & 10 & 150,909 & $0.09-0.82$ & - & - & Paspalum conjugatum & 133.74 \\
\hline & Seedling & 2 & 454 & $0.09-0.09$ & - & - & Acacia mangium/Shorea $\mathrm{sp}$ & 100.00 \\
\hline & Sapling & 6 & 544 & $0.09-0.27$ & $5-9.6$ & 2.13 & Enterolobium cyclocarpum & 135.88 \\
\hline & Pole & 7 & 300 & $0.09-0.45$ & $10-19.5$ & 4.58 & Enterolobium cyclocarpum & 129.87 \\
\hline & Tree & 2 & 107 & $0.18-0.45$ & $20-40.5$ & 6.34 & Enterolobium cyclocarpum & 263.74 \\
\hline
\end{tabular}

Note: K: Density, D: Dominance, IVI: Importance Value Index 
The tree stand structure also represents the relationship between the number of trees and the diameter class (Irawan, 2011). Tree diameter in this study was grouped into five classes, namely $0 \leq 10 \mathrm{~cm} ; 10-\leq 20 \mathrm{~cm} ; 20-\leq 30 \mathrm{~cm}$; $30-\leq 40 \mathrm{~cm} ; 40-\leq 50 \mathrm{~cm}$. The number of trees in the sample plots from each stratum in each diameter class is then converted to the number of individuals per hectare so a diameter class distribution structure formed is as shown in Figure 4. The horizontal stand structure based on the distribution of diameter classes on post-mining areas with revegetation ages of 11 years, 10 years, 8 years, and 5 years has resembled a natural forest as shown by the inverted $\mathbf{J}$ curve.
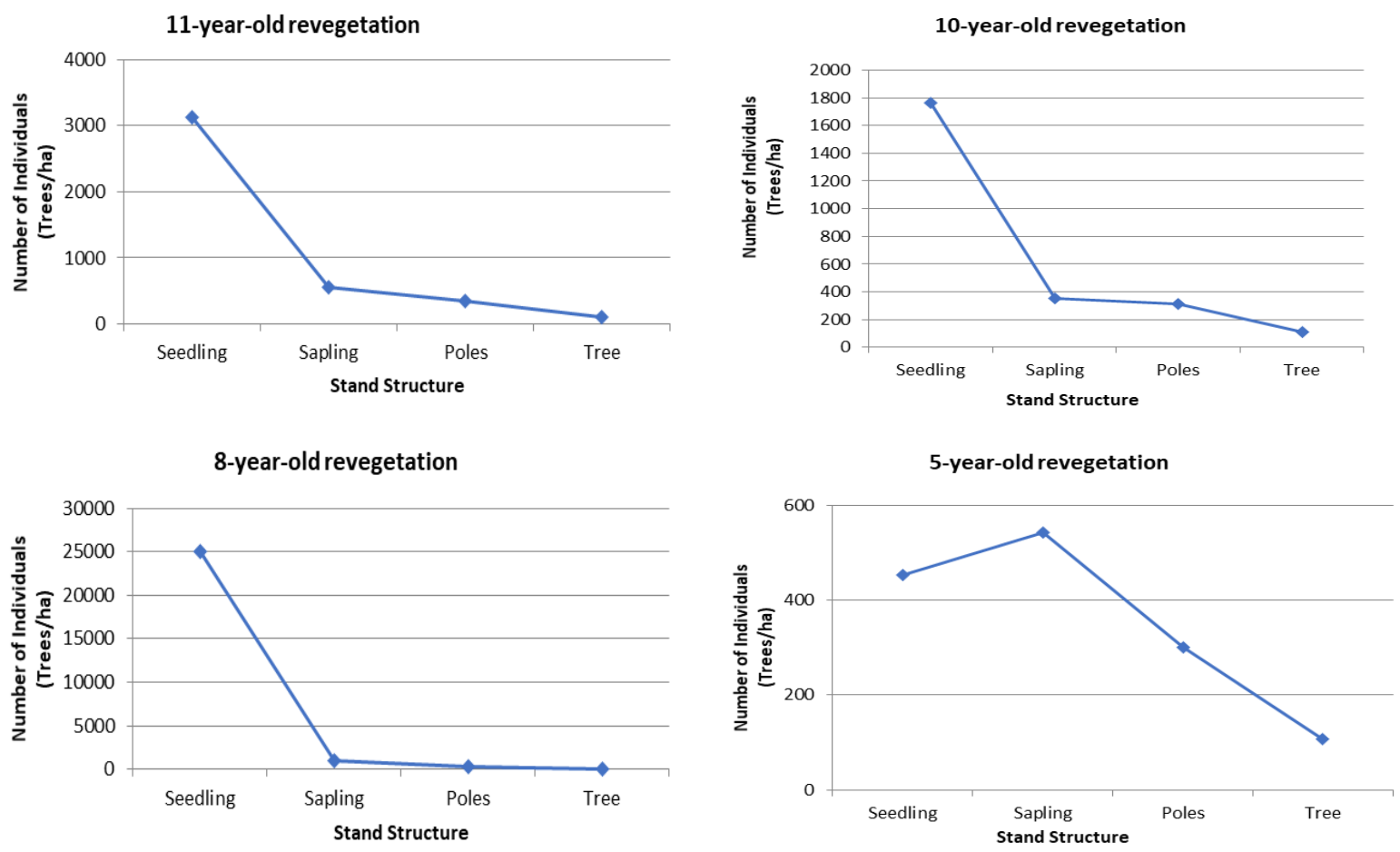

Figure 3. The curve of stand structure across strata at varying post-mining revegetation ages
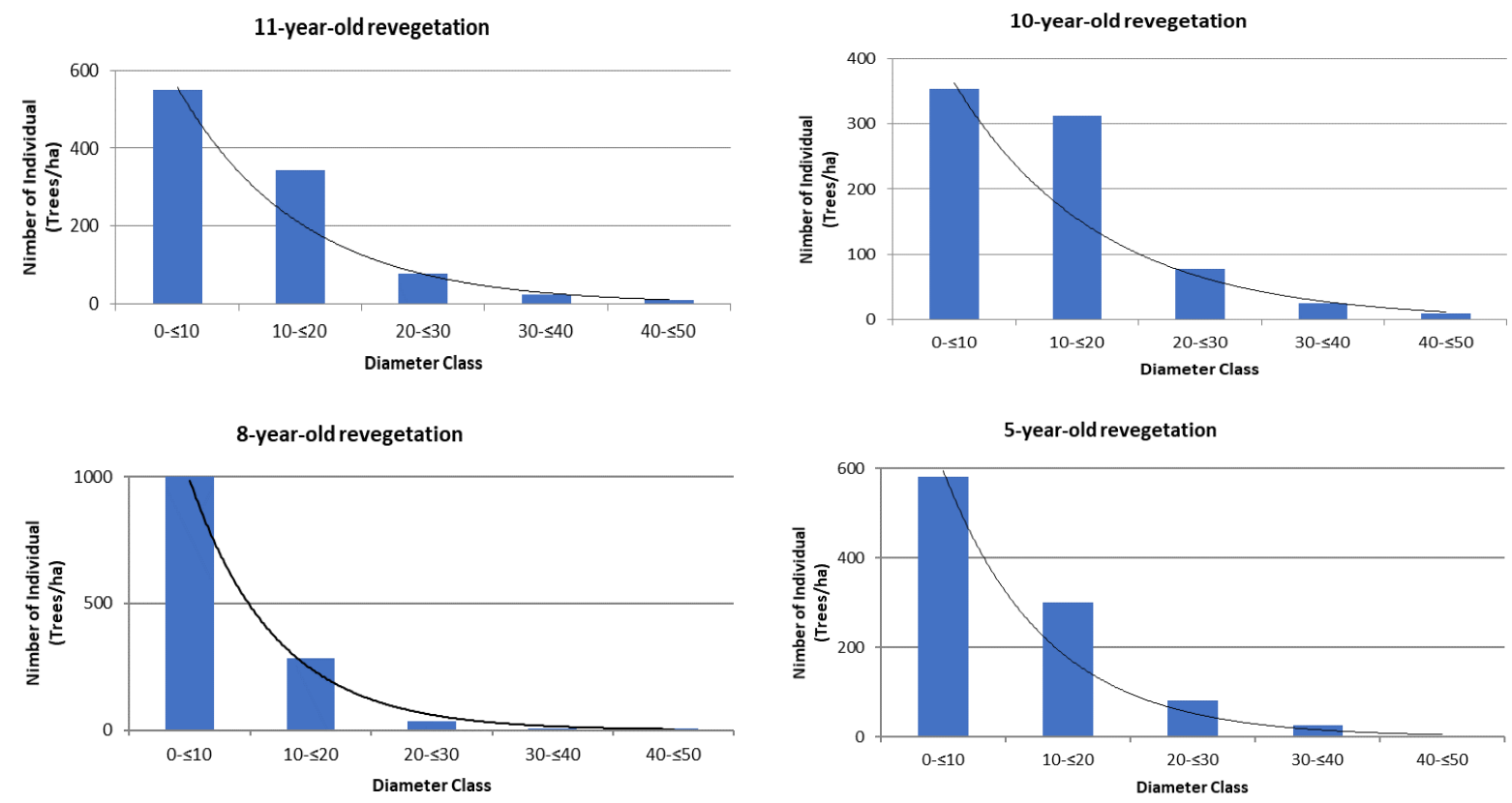

Figure 4. The curve of stand structure of trees across diameter classes at varying post-mining revegetation ages 
Table 5. Species richness index, diversity index, and evenness index at varying strata and revegetation ages

\begin{tabular}{|c|c|c|c|c|c|c|c|c|c|c|c|c|}
\hline \multirow{2}{*}{ Stratum } & \multicolumn{4}{|c|}{ Species Richness Index (R) } & \multicolumn{4}{|c|}{ Shannon Index (H') } & \multicolumn{4}{|c|}{ Evenness Index (E) } \\
\hline & 11 & 10 & 8 & 5 & 11 & 10 & 8 & 5 & 11 & 10 & 8 & 5 \\
\hline Understorey & 1.90 & 2.18 & 0.95 & 1.38 & 2.00 & 2.30 & 1.62 & 1.35 & 0.76 & 0.85 & 0.91 & 0.59 \\
\hline Seedling & 1.47 & 0.69 & 1.95 & 1.44 & 1.71 & 1.04 & 1.87 & 0.69 & 0.95 & 0.95 & 0.85 & 1.00 \\
\hline Sapling & 1.72 & 1.48 & 1.85 & 1.85 & 1.68 & 1.28 & 1.53 & 1.53 & 0.83 & 0.80 & 0.85 & 0.85 \\
\hline Poles & 1.59 & 1.01 & 1.76 & 1.72 & 1.92 & 1.44 & 1.66 & 1.60 & 0.88 & 0.89 & 0.93 & 0.82 \\
\hline Tree & 1.70 & 1.38 & 0.80 & 0.26 & 1.61 & 1.24 & 0.99 & 0.37 & 0.73 & 0.64 & 0.90 & 0.53 \\
\hline
\end{tabular}

Notes: 11, 10, 8, 5: Vegetation age (years)

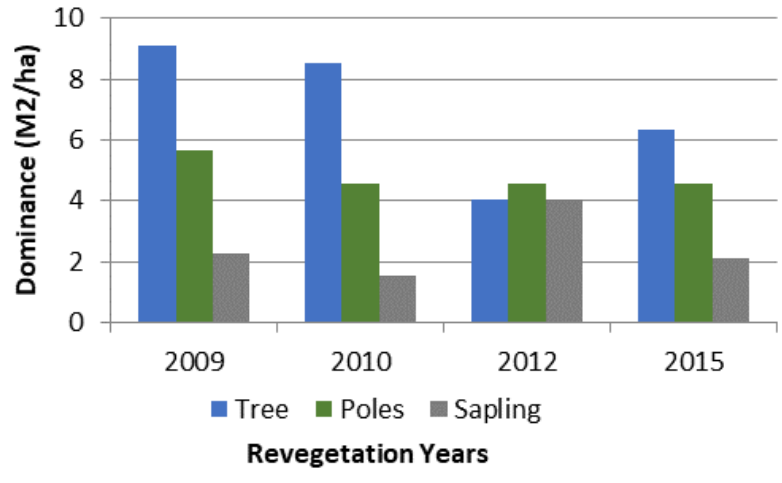

Figure 5. The basal area of the vegetation (dominance) at varying strata and revegetation ages

Dominance is a value that shows the amount of space used by each species in an area unit (e.g., $\mathrm{m}^{2} / \mathrm{ha}$ ). The dominance of each vegetation type is calculated based on the basal area of stem; thus, the degree of the dominance is also influenced by the density and the average stem diameter of the same species. The dominance values of saplings, poles, and trees from each revegetation year are presented in Figure 5. Since the dominance is a function of species density and stem diameter, the level of dominance describes the total area covered by the basal of vegetation (Gunawan et al. 2011).

\section{Biodiversity indicators of vegetation community}

The ecological significance at species level is assessed through Important Value Index (IVI) which indicates the role of the species in the community or research site (Gunawan et al. 2011). IVI is obtained by sum up the relative values of the three parameters (relative density, relative frequency, and relative dominance), thus the IVI also varies for each vegetation type. According to Sundarapandian and Swamy (2000), the important value index is one of the parameters that may provide an overview of the function of specific species in the community or research site. The IVI of all species then serves as the basis for calculating Shannon-Wiener diversity index $\left(\mathrm{H}^{\prime}\right)$ (Magurran 1988), while the evenness index of a species is determined based on the species diversity index. There are three categories used in the analysis of the species diversity index, namely $\mathrm{H}^{\prime}<2$ means low diversity, $2 \leq \mathrm{H}^{\prime}<3$ means medium diversity, and $H^{\prime} \geq 3$ means high diversity (Magurran 1988). The Species Richness Index (R) is calculated using the
Margalef formula (Magurran 1988) in which $\mathrm{R}<3.5$ indicates low richness index, $3.5 \leq \mathrm{R}<5.0$ indicates medium richness, and $\mathrm{R} \geq 5.0$ indicates high richness index. Evenness index $(\mathrm{E})$ is low when the value of $\mathrm{E}<$ 0.3 , moderate when $0.3 \leq \mathrm{E}<0.6$, and high when $\mathrm{E} \geq 0.6$. The three indices of species richness (R), diversity $\left(\mathrm{H}^{\prime}\right)$ and evenness (E) are components of biodiversity indicators (Magurran 1988). The value of the species richness index $(\mathrm{R})$, diversity index $(\mathrm{H})$, and species evenness index (E) of the research samples are presented in (Table 5).

The results of this study found species richness index (R) in each stratum in all revegetation ages were in low richness category as indicated by $\mathrm{R}$ value of $<3.5$. The average diversity index value $(\mathrm{H})$ was also discovered to be in the low category with $\mathrm{H}<2$. However, in the understorey strata, the 11-year-old and 10-year-old revegetation sites were in the medium category with $\mathrm{H}$ values equal to 2.0 and 2.3 , respectively. This index is lower than the diversity index of natural forests but still higher compared to degraded natural forests as found by Kusumo et al. (2016) who stated that Shannon-Wiener diversity index in natural forests is 2.18 for seedling, 2.05 for sapling, 2.34 for pole, and 3.05 for tree level. In degraded natural forests, the index is 0.05 for seedling, 0.1 for sapling, 1.31 for pole, and 1.16 for tree.

The average evenness index was categorized as high as indicated by $\mathrm{E}>0.6$. The understorey and 5-year-old trees are included in the medium category with $\mathrm{E}$ value of 0.59 and 0.53 . The evenness index of a species is determined by the distribution of each species on every plot uniformly. The more evenly distributed a species is in an ecosystem, the higher the evenness index (Gunawan et al. 2011). Thus, the diversity index can be used as an indicator in comparing forest stand settings and the ecological characteristics (Ng et al. 2009) and species richness (Sodhi et al. 2010). In general, the ecosystems in damaged forests have poor species diversity or decreased diversity of vegetation types (Setyowati et al. 2017).

In conclusion, based on the research data obtained, we conclude that the structure of vegetation in post-coal mining reclamation areas in the studied site was better than in degraded forest and although did not yet reach the vegetation condition in natural forest ecosystem. The conclusion is made through an analytical approach on the number of trees and the distribution of tree diameter at 11 year-, 10 year-, and 8-year-old of revegetation. Meanwhile, in $5^{\text {th }}$ year, the natural forest stand structure was analyzed only through distribution of diameter class. However, the 
diversity index is still relatively low and is below the diversity index of a natural forest at all revegetation ages being studied.

\section{ACKNOWLEDGEMENTS}

The author would like to thank the General Manager of PT. Bukit Asam, Tbk Tanjung Enim, South Sumatra, Indonesia for allowing this research to be conducted in the Company's operational area, and to the revegetation team and the environmental control team of IUP TAL Western Block who have assisted in collecting field data. Similarly, great appreciation is conveyed to Noril Milantara for his support in data analysis and Jun Harbi for all supports in the writing process of this article.

\section{REFERENCES}

Arrijani, Setiadi D, Guharja E, Qoyim I. 2006. Vegetation analysis of the upstream Cianjur watersheds in Mount Gede-Pangrango National Park. Biodiversitas 7: 147-153. DOI: 10.13057/biodiv/d070212.

BSN. 2014. SNI 7645-1:2014 Klasifikasi penutup lahan-Bagian 1 : Skala kecil dan menengah. Sni 7645-1, 1-51. [Indonesian]

Fajri M, Garsetiasih R. 2019. Komposisi jenis vegetasi lahan pasca tambang Galian C di Khdtk Labanan, Kabupaten Berau. J Penelitian Hutan dan Konservasi Alam 16: 101-118. [Indonesian]

Favas PJ de C, Martino LE, Prasad MNV. 2018. Abandoned Mine Land Reclamation-Challenges and Opportunities (Holistic Approach), BioGeotechnologies for Mine Site Rehabilitation. Elsevier Inc., Nederland.

Ghose MK. 2005. Soil conservation for rehabilitation and revegetation of mine-degraded land. TIDEE (TERI Inf. Dig. Energy Environ) 4: 137150.

Gunawan W, Basuni S, Indrawan A, Prasetyo LB, Soedjito H. 2011. Analisis komposisi dan struktur vegetasi terhadap upaya restorasi Kawasan Hutan Taman Nasional Gunung Gede Pangrango. J Nat Resour Environ Manag 1: 93-93. [Indonesian]

Haibin L, Zhenling L. 2010. Recycling utilization patterns of coal mining waste in China. Resour Conserv Recycl 54: 1331-1340.

Hapsari L, Trimanto T, Budiharta S. 2020. Spontaneous plant recolonization on reclaimed post-coal mining sites in East Kalimantan, Indonesia: Native versus alien and succession progress. Biodiversitas 21 (5): 2003-2018. DOI: 10.13057/biodiv/d210527.

Istomo, Aji Nuralam, Dwisutono. 2016. Struktur dan komposisi tegakan serta sistem perakaran tumbuhan pada kawasan karst di Taman Nasional Bantimurung-Bulusaraung, Resort Pattunuang-Karaenta. J Silvikuktur Tropika 7: 58-67. [Indonesian]

Komara LL, Choesin DN, Syamsudin TS. 2016. Plant diversity after sixty years post coal mining in East Kalimantan, Indonesia. Biodiversitas 17: 531-538. DOI: 10.13057/biodiv/d170220.

Kumar BM. 2013. Mining waste contaminated lands: an uphill battle for improving crop productivity. J Degrad Min Lands Manag 1: 43-50.

Kusumo A, Nur Bambang A, Izzati M. 2016. Struktur vegetasi kawasan hutan alam dan hutan terdegradasi di Taman Nasional Tesso Nilo. J Ilmu Lingkungan 14: 19. [Indonesian]

Kuswandana W. 2010. Pengaruh kerapatan tumbuhan terhadap populasi burung. J Penelit Hutan dan Konserv Alam 8: 193-213. [Indonesian]

Kuswandi R, Sadono R, Supriyatno N, Djoko M. 2015. Diversity of stand structure in logged-over forest based on Papua biogeography. J Manusia dan Lingkungan 22: 151-159. [Indonesian]

Lestari DA, Fiqa AP, Fauziah, Budiharta S. 2019. Growth evaluation of native tree species planted on post-coal mining reclamation site in East Kalimantan, Indonesia. Biodiversitas 20: 134-143. DOI: 10.13057/biodiv/d200116

Magurran AE. 1988. Measuring Biological Diversity. Blackwell Publishing Ltd., UK.

Martono DS. 2012. Analisis vegetasi dan asosiasi antara jenis-jenis pohon utama penyusun hutan tropis dataran rendah di Taman Nasional
Gunung Rinjani Nusa Tenggara Barat. Agri-tek 13: 18-27. [Indonesian]

Menteri Kehutanan. 2006. Peraturan Menteri Kehutanan Nomor. P.67/Menhut-II/2006 tentang Kriteria dan Standar Inventarisasi Hutan. Jakartan. [Indonesian]

Mukhtar AS, Heriyanto NM. 2012. Keadaan suksesi tumbuhan pada kawasan bekas tambang batubara di Kalimantan Timur. Penelit. dan Konserv Alam 9: 341-350. [Indonesian]

Murdjoko A, Jitmau MM, Djitmau DA, Siburian RHS, Ungirwalu A, Wanma AO, Mardiyadi Z, Rumatora A, Mofu WY, Sineri AS, Fatem SM, Worabai D, May NL, Tokede MJ, Warmetan H, Wanggai CB, Wanma JF, Sirami EV, Paembonan JB, Unenor E, Kuswandi R, Lekitoo K, Khayati L, Benu NMH, Tambing J, Saragih ASB. 2020. Heterospecific and conspecific associations of trees in lowland tropical forest of New Guinea. Biodiversitas 21: 4405-4415. DOI: $10.13057 /$ biodiv/d210960

$\mathrm{Ng}$ KKS, Lee SL, Ueno S. 2009. Impact of selective logging on genetic diversity of two tropical tree species with contrasting breeding systems using direct comparison and simulation methods. For Ecol Manag 257 107-116. DOI: 10.1016/j.foreco.2008.08.035

Paga B, Pudyatmoko S, Faida LRW, Yuda IP, Sulaksono N. 2021. Characteristics of vegetation as determinant of Timor Friarbird (Philemon inornatus) distribution in Bipolo Landscape of West Timor Island, Indonesia. Biodiversitas 22, 2617-2635. DOI: 10.13057/biodiv/d220521

Pamoengkas P, Rachmat HH, Khalifa N. 2020. The growth of Shorea leprosula at various planting distances and slopes in Gunung Dahu research forest, Bogor, Indonesia. Biodiversitas 21: 4396-4404. DOI: 10.13057/biodiv/d210959.

Rusolono T, Tiryana T, Purwanto J, Sumantri H. 2015. Panduan Survei Cadangan Karbon dan Keanekaragaman Flora di Sumatera Selatan. GIZ Biodiversity and Climate Change (BIOCLIME), Palembang [Indonesian]

Sembiring S. 2008. Sifat kimia dan fisik tanah pada areal bekas tambang bauksit di Pulau Bintan, Riau. Info Hutan 5: 123-134. [Indonesian]

Septiawan W, Indriyanto I, Duryat D. 2017. Species, density, and canopy stratification of social forestry of the farmers group Rukun Makmur 1 in Register 30 Mount Tanggamus Lampung. J Sylva Lestari 5: 88. DOI:10.23960/js12588-101

Setiadi Y, Adinda. 2013. Evaluation of growth in post-mining revegetation land PT. Vale Indonesia Tbk. Sorowako, South Sulawesi. J Silvikultur Tropika 4 (1): 19-22. [Indonesian]

Setyowati R, Amala, N, Aini N. 2017. Studi pemilihan tanaman revegetasi untuk keberhasilan reklamasi lahan bekas tambang. Al-Ard: Jurnal Teknik Lingkungan 3 (1): 14-20. DOI: 10.29080/alard.v3i1.256. [Indonesian]

Sheoran V, Sheoran A, Poonia P. 2010. Soil reclamation of abandoned mine land by revegetation: a review. Intl J Soil Sediment Water 3: 120 .

Singh AN, Raghubanshi AS, Singh JS. 2002. Plantations as a tool for mine spoil restoration. Curr Sci 82 (12): 1436-1441

Sodhi NS, Koh LP, Clements R, Wanger TC, Hill JK, Hamer KC, Clough Y, Tscharntke T, Posa MRC, Lee TM. 2010. Conserving Southeast Asian forest biodiversity in human-modified landscapes. Biol Conserv 143: 2375-2384. DOI: 10.1016/j.biocon.2009.12.029.

Sundarapandian S, Swamy PS. 2000. Forest Ecosystem structure and composition along an altitudinal gradient in the Western Ghats, South India. J Trop For Sci 12: 104-123.

Toren T. 2002. Determination of environmental impacts due to open pit coal mining activities: a case study from Turkey. Proc SWEMP 7-10.

Triantoro A. 2017. Studi reklamasi lahan bekas tambang batubara PT.Bhumi Rantau Energi di Rantau Kalimantan Selatan. Geosapta 3: 107-110. [Indonesian]

Witno, Puspaningsih N, Kuncahyo B. 2018. Model pendugaan biomassa di areal revegetasi bekas tambang nikel. Media Konservasi 23: 293302. [Indonesian]

Yani M. 2005. Reklamasi Lahan Bekas Tambang dengan Penanaman Jarak Pagar. Seminar Nasional Pengembangan Jarak Pagar (Jatropha curcas Linn) Untuk Biodiesel dan Minyak Bakar, Begor, 22 Desember 2005. [Indonesain]

Zhongke B, Jingkui Z, Jinchuan L. 1999. Ecosystem damage in a large opencast coal mine-A case study on Pingshuo surface coal mine. Acta Ecol Sin 19: 870-875. 